\title{
72. Effect of the Corpus Allatum Hormone on Carbohydrate and Nitrogen Metabolism in Bombyx mori
}

\author{
By Seijiro Morohoshi, Tadahiko IIJIMA, Shin-ichi KIKUCHI, \\ and Shin-ichi IKEDA
}

(Comm. by Yoshimaro TanakA, M, J. A., April 12, 1969)

Morohoshi (1957) advocated from the physiogenetical viewpoint that the corpus allatum (CA) and suboesophageal ganglion (SG) hormones act antagonistically. Hasegawa and Yamashita (1967) demonstrated that the SG hormone accelerates the accumulation of glycogen into the fat body or pupal ovaries. Morohoshi and Kiguchi (1969) found that the CA hormone accelerates the release of lipid from the fat body into blood. That is, these two hormones act antagonistically on the lipid metabolism of the silkworm. This paper treats the effect of the C.A and SG on carbohydrate and nitrogen metabolism of the silkworm.

Materials and methods. Two pairs of the CA collected from 4 th or 5 th instar larvae were inserted into the 5 th segment of recipient larvae. Recipients were female 5th instar larvae and donors were males from the same batch. Two SG removed from 4th or 5th instar larvae were transplanted into the 5th segment of the same instar larva. Removal of the two CA was carried out on the 1st day of the 4 th and 5th instar, and allatectomy at the early period of the 4th instar was followed by the appearance of trimolters. Removal of the SG was done on the day of pupation. The control groups were also operated upon, because the issue of blood by transplantation or extirpation may be responsible for the deviation of data.

Blood was collected in chilled test tubes by cutting abdominal legs and preserved in a freezer. The eggs used in the experiments were collected by dissection from newly emerged moths. Oviducts were put aside in distilled water. Isolated eggs were put on filter papers to exclude moisture and then stored in freezer. Before chemical analysis, eggs were dried in vacuo for 5 hours and they were weighed. Total carbohydrates were measured by the phenol-sulfuric acid method (Dubois et al., 1956). Determination of nitrogen content was made by the micro-Kjeldahl method.

Results. Blood sugar contents in larval blood were higher in low incubating temperatures than in high incubating temperatures, as shown in Tables I and II. Blood sugar levels during the 5th 
larval development decreased at the 2nd day of the 5th instar and slowly increased with age. Blood sugar content in allatectomized silkworms decreased more than in the incised controls in both high incubating temperatures as well as in low incubating temperatures, while transplantation of the CA resulted in a rise of blood sugar level. The difference of blood sugar content between allatectomized and controlled larvae was greater during the pupal stage than during the 5th instar.

Table I. Change of blood sugar content in allatectomized $(-\mathrm{CA})$ or corpora allata transplanted $(+\mathrm{CA})$ silkworms

\begin{tabular}{|c|c|c|c|c|c|c|c|c|c|c|}
\hline \multirow{2}{*}{$\begin{array}{l}\text { Temperature } \\
\text { during incu- } \\
\text { bation (race) }\end{array}$} & \multirow{2}{*}{$\begin{array}{l}\text { Experi- } \\
\text { ment }\end{array}$} & \multicolumn{6}{|c|}{ The day of $5 \mathrm{th}$ instar $(\mathrm{mg} / \mathrm{ml})$} & \multicolumn{3}{|c|}{$\begin{array}{l}\text { The day of pupa } \\
(\mathrm{mg} / \mathrm{ml})\end{array}$} \\
\hline & & $1 \mathrm{st}$ & 2nd & $3 r d$ & 4 th & 5 th & 6 th & 1 st & $3 r d$ & 4 th \\
\hline \multirow{2}{*}{$\begin{array}{c}25^{\circ} \mathrm{C} \\
(\text { Shungestu } \\
\times \text { Hosho) }\end{array}$} & Control & 3.07 & 2.75 & 3.49 & 3.80 & 4.25 & 4.87 & 4.20 & 3.52 & 5.09 \\
\hline & $-\mathrm{CA}$ & 3.30 & 2.16 & 2.83 & 3.22 & 4.15 & 4.39 & 2.53 & 2.31 & 4.11 \\
\hline \multirow{3}{*}{$\begin{array}{c}17^{\circ} \mathrm{C} \\
\text { (J. No. } 106 \\
\times \text { Daizo) }\end{array}$} & Control & 2.66 & 3.53 & 4.42 & 4.17 & & & & & \\
\hline & $-\mathrm{CA}$ & 2.66 & 3.09 & 4.29 & 3.21 & & & & & \\
\hline & $+\mathrm{CA}$ & 3.29 & 4.40 & 4.67 & 4.64 & & & & & \\
\hline
\end{tabular}

Table II. Effect of transplantation or removal of the CA or SG on glycogen content in eggs (J. No. $106 \times$ Daizo race)

\begin{tabular}{|c|c|c|c|c|c|c|c|c|c|}
\hline \multirow{2}{*}{ Voltinism } & \multirow{2}{*}{$\begin{array}{l}\text { Control } \\
\text { (A) } \\
(\mathrm{mg} / \mathrm{ml})\end{array}$} & \multicolumn{2}{|c|}{$-\mathrm{CA}$} & \multicolumn{2}{|c|}{$+\mathrm{CA}$} & \multicolumn{2}{|c|}{$-\mathrm{SG}$} & \multicolumn{2}{|c|}{$+\mathrm{SG}$} \\
\hline & & $-\mathrm{CA}(\mathrm{B})$ & $\mathrm{B}-\mathrm{A}$ & $+\mathrm{CA}(\mathrm{C})$ & $\mathrm{C}-\mathrm{A}$ & $-\mathrm{SG}(\mathrm{D})$ & $\mathrm{D}-\mathrm{A}$ & $+\mathrm{SG}(\mathrm{E})$ & $\mathrm{E}-\mathrm{A}$ \\
\hline & & 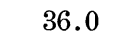 & 1 & - & - & 29.1 & -6.3 & - & - \\
\hline on-diapause & 25.9 & 28.0 & +2.1 & 21.6 & -4.3 & 24.8 & -1.1 & 34.0 & +8.1 \\
\hline
\end{tabular}

Effect of transplantation or removal of the CA or SG on glycogen contents in newly produced eggs is shown in Table II. Glycogen content in eggs was greater in diapause eggs than in non-diapause eggs. Allatectomy (-CA) led to increase of the amount of glycogen in eggs though the difference was slight. Transplantation (+CA) of the CA into "non-diapause silkworms" decreased considerably glycogen contents. Removal (-SG) of the SG from "diapause silkworms" or transplantation $(+\mathrm{SG})$ of the organ into "nondiapause silkworms" showed a considerable difference of glycogen contents but extirpation of the organ from "non-diapause silkworms" showed little difference as compared with the incised controls. From these results it is considered that the above two hormones are related to the determination of voltinism. However, the suboesophageal ganglion hormone seems to be the main determiner of voltinism, 
and the corpus allatum hormone the secondary determiner.

Total nitrogen content in larval blood was higher in high temperatures than in low temperatures during incubation, as shown in Table III. It was observed that total nitrogen contents in larval blood decreased with transplantation of the CA, while it increased with removal of the organ. Total nitrogen in eggs, however, was lower in high temperatures than in low temperatures during incubation, as shown in Tables IV and V. Total nitrogen contents in eggs were higher in transplantation of the CA and in extirpation of the SG than in the incised controls, and also they were lower in allatectomy and in transplantation of the SG than in the incised controls.

Table III. Nitrogen metabolism in larval blood of allatectomized or corpora allata transplanted silkworms (J. No. $106 \times$ Daizo race)

\begin{tabular}{|c|c|c|c|c|c|c|c|c|}
\hline \multirow{2}{*}{$\begin{array}{c}\text { Temperature } \\
\text { during } \\
\text { incubation }\end{array}$} & \multirow{2}{*}{ Experiment } & \multicolumn{7}{|c|}{ The day of 5 th instar $(\mathrm{mg} / \mathrm{ml})$} \\
\hline & & 1st & 2nd & $3 \mathrm{rd}$ & 4 th & 5 th & 6 th & 7 th \\
\hline \multirow{3}{*}{$\begin{array}{c}25^{\circ} \mathrm{C} \\
\text { (Diapause) }\end{array}$} & Control & 4.84 & 5.84 & 10.80 & 12.64 & 14.13 & 14.27 & 10.79 \\
\hline & $-\mathrm{CA}$ & 4.64 & 6.35 & 11.72 & 13.14 & 13.70 & 12.37 & 10.51 \\
\hline & $+\mathrm{CA}$ & 一 & 5.67 & - & 12.14 & - & 11.30 & 一 \\
\hline $17^{\circ} \mathrm{C}$ & Control & 4.02 & 5.82 & 9.51 & 10.51 & 12.21 & 11.50 & 10.65 \\
\hline \multirow[b]{2}{*}{ (Non-diapause) } & $-\mathrm{CA}$ & 4.09 & 6.02 & 10.01 & 11.43 & 13.06 & 10.51 & 10.65 \\
\hline & $+\mathrm{CA}$ & 4.01 & - & 8.31 & - & 9.93 & - & 10.11 \\
\hline
\end{tabular}

Table IV. Effect of the AC and SG hormones on nitrogen metabolism in eggs (Cambodge $\times$ Kojiki race)

\begin{tabular}{c|c|c|c|c|c|c}
\hline $\begin{array}{c}\text { Temperature } \\
\text { during } \\
\text { incubation }\end{array}$ & $\begin{array}{c}\text { Ex- } \\
\text { periment }\end{array}$ & Age & $\begin{array}{c}\text { Total nitrogen } \\
\text { (mg/100 mg of } \\
\text { dried eggs) }\end{array}$ & \multicolumn{2}{|c}{ Water soluble nitrogen } \\
\cline { 5 - 7 } $25^{\circ} \mathrm{C}$ & Control & $1 / \mathrm{V}$ & 5.97 & 1.04 & 0.54 & 0.50 \\
(Diapause) & $+\mathrm{CA}$ & $1 / \mathrm{V}$ & 6.53 & 1.21 & 0.58 & 0.63 \\
& $-\mathrm{SG}$ & $1 / \mathrm{P}$ & 6.61 & 1.52 & 0.98 & 0.54 \\
\hline $17^{\circ} \mathrm{C}$ & $\mathrm{Control}$ & $1 / \mathrm{V}$ & 6.81 & 1.30 & 0.71 & 0.59 \\
protein
\end{tabular}

$1 / \mathrm{V}$ : operated at 1 st day of 5 th instar; 1/P: operated at 1st day after putation.

Discussion. The hormonal control of synthesis in adult fat body has been studied in several insects. The rate of incorporation of $\mathrm{C}^{14}$ glycine into protein during oögenesis in Schistocerca decreases after allatectomy, and after removal of the median neurosecretory cells of the brain (Hill, 1965). Lüscher (1968) observed that in 
Table V. Effect of transplantation of removal of the CA or SG on nitrogen content in eggs (J. No. $106 \times$ Daizo race)

\begin{tabular}{c|c|c|c|c}
\hline $\begin{array}{c}\text { Temperature } \\
\text { during } \\
\text { incubation }\end{array}$ & Experiment & Age & $\begin{array}{c}\text { Total nitrogen } \\
\text { (mg/100 mg of } \\
\text { dried eggs) }\end{array}$ & $\begin{array}{c}\text { Number of eggs } \\
\text { in 100 mg of } \\
\text { dried eggs }\end{array}$ \\
\hline $25^{\circ} \mathrm{C}$ & Control & $1 / \mathrm{V}$ & 9.57 & 180 \\
\cline { 2 - 4 } (Diapause) & $-\mathrm{CA}$ & $1 / \mathrm{V}$ & 9.01 & 173 \\
& $+\mathrm{CA}$ & $1 / \mathrm{V}$ & 10.01 & 188 \\
& $-\mathrm{SG}$ & $1 / \mathrm{P}$ & 10.65 & 189 \\
\hline $17^{\circ} \mathrm{C}$ & Control & $1 / \mathrm{V}$ & 10.91 & 182 \\
& $-\mathrm{CA}$ & $1 / \mathrm{V}$ & 10.05 & 174 \\
(Non-diapause) & $+\mathrm{SG}$ & $1 / \mathrm{V}$ & 10.59 & 181 \\
\hline
\end{tabular}

allatectomized Leucophaea adults protein synthesis in the fat body is stimulated by implanted corpora allata. In Rhodnius the synthesis of the proteins which are incorporated in the yolk seems to occur in the fat body under the influence of the corpora allata (Vanderberg, 1963 a, b ; Coles, 1964, 1965).

As to the effect of the CA and SG on carbohydrate metabolism, Odhiambo $(1965,1966)$ has reported that allatectomy of newly emerged adult locusts resulted in the accumulation of fat and glycogen. Yamashita and Hasegawa $(1963,1964,1965)$ reported in Bombyx mori that an increase of the SG hormone accelerated the glycogen accumulation in the fat body or pupal ovaries, with a concomitant decrease of blood sugar level. The effect of the CA and SG hormones on carbohydrate metabolism in Bombyx mori was similar to the results in lipid metabolism (Morohoshi and Kiguchi, 1969).

As to the effect of the CA and SG hormones on nitrogen metabolism, it was observed that the transplantation of the SG increased the amount of total nitrogen in larval blood but decreased it in eggs, and that the extirpation of the SG decreased the amount of total nitrogen in larval blood but increased it in eggs. The transplantation of the CA decreased total nitrogen in larval blood and increased in it eggs.

If soft mulberry leaves are given to tetramolting larvae during early larval stages, some of them tend to become trimolters. If the same mulberry leaves are given to the 5th instar larvae, they lengthen the larval development. These may be due to the soft mulberry leaves having greater nitrogen content. The increase of the CA hormone also shows similar results. The weight of pupae developed from allatectomized larvae was $85 \%$ that of the incised controls. This may be due to depression of nitrogen metabolism as a result of allatectomy. If silkworms are allatectomized on the 1st day of the 5th instar, their silkglands rapidly develop. This may perhaps be because 
the excretion of nitrogen into silkglands is performed owing to less or no accumulation of total nitrogen into other tissues.

From the above data, it is understood that the SG hormone accelerates the accumulation of carbohydrate and lipid in the fat body or eggs and decelerates the accumulation of total nitrogen into some tissues (fat body?), and the CA hormones accelerates the accumulation of total nitrogen into some tissues or eggs and the release of glycogen and lipid from the fat body.

Morohoshi (1957) has assumed that from the physiogenetical point of view the CA and SG hormones act antagonistically. Later Ralph (1962) reported that the extract of the corpus-cardiacumcompound and that of the SG acted antagonistically on the heartbeat in the cockroach. Morohoshi and Ohkuma (1968) observed also two kinds of active substances in the extracts from the CA and SG of the silkworm having an accelerating and a decelebrating action on the silkworm heart, respectively.

"Bivoltine larvae" incubated at low temperature and in the dark showed the similar results as transplantation of the $\mathrm{CA}$ for the rise and fall of lipid, carbohydrate and nitrogen metabolism in larval blood and eggs, and when incubated at high temperature and in the light showed similar results as transplantation of the SG for the rise and fall. Similar results have also been demonstrated by Bito (1936).

There are two important self-regulating characteristics during the life cycle of the silkworm; one is molting characteristic which controls molt numbers, and the other is voltine characteristic which controls generation numbers. Although the two characteristics are determined by the antagonistic function of the two hormones, the former is predominantly determined by the function of the braincorpora allata system $(\mathrm{Br}+\mathrm{CA})$ during early development, as shown in Fig. 3 of Report 68 of this series by Morohoshi and Oshiki and the latter is predominantly determined by the function of the brainsuboesophageal ganglion system $(\mathrm{Br}+\mathrm{SG})$ during later development. These relationships can be replaced with accumulation of nitrogen (N) against accumulation of carbohydrate and lipid (C). The development in the silkworm is controlled by the ratio of amounts of nitrogen versus carbohydrate and lipid: the molting characteristic during early development is predominantly determined by accumulation of nitrogen $(\mathrm{N})$, and the voltine characteristic during later development is predominantly determined by accumulation of carbohydrate and lipid (C). This $\mathrm{N} / \mathrm{C}$ ratio must be related to photoperiodism in insects.

From the above results, relationships between the amount of CA or SG hormones and the change of molting or voltine characteris- 
Table VI. Relationship between the amount of CA or SG hormones and the change of molting or voltine characteristics

\begin{tabular}{|c|c|c|c|c|c|c|c|}
\hline \multirow[b]{2}{*}{$\begin{array}{l}\text { Condi- } \\
\text { tion }\end{array}$} & \multicolumn{2}{|c|}{$\begin{array}{l}\text { Carbohydrate } \\
\text { and lipid }\end{array}$} & \multicolumn{2}{|c|}{$\begin{array}{l}\text { Total } \\
\text { nitrogen }\end{array}$} & \multirow[b]{2}{*}{$\begin{array}{l}\text { Ener- } \\
\text { gy me- } \\
\text { tabo- } \\
\text { lism }\end{array}$} & \multirow[b]{2}{*}{$\begin{array}{l}\text { Change direc- } \\
\text { tion of } \\
\text { molting } \\
\text { during early } \\
\text { development }\end{array}$} & \multirow[b]{2}{*}{$\begin{array}{l}\text { Change direc- } \\
\text { tion of vol- } \\
\text { tinism } \\
\text { during later } \\
\text { development }\end{array}$} \\
\hline & $\begin{array}{c}\text { Accu- } \\
\text { mula- } \\
\text { tion } \\
\text { into fat } \\
\text { body }\end{array}$ & \begin{tabular}{|c} 
Con- \\
sump- \\
tion \\
(release \\
into \\
blood)
\end{tabular} & \begin{tabular}{|c|} 
Accu- \\
mula- \\
tion \\
(eggs \\
or \\
tissues)
\end{tabular} & $\begin{array}{l}\text { Excre- } \\
\text { tion } \\
\text { into } \\
\text { silk- } \\
\text { glands }\end{array}$ & & & \\
\hline $\begin{array}{l}\text { Increase } \\
\text { of CA } \\
\text { hormone } \\
\text { (low in- } \\
\text { cubating } \\
\text { temper- } \\
\text { ature }\end{array}$ & Less & More & More & Less & Rise & $\begin{array}{l}\underset{\uparrow}{\text { Trimolting }} \\
\underset{\uparrow}{\text { Tetramolting }} \\
\uparrow \\
\text { Pentamolting } \\
\text { (Domination) }\end{array}$ & $\begin{array}{l}\underset{\uparrow}{\text { Multivoltine }} \\
\uparrow \\
\text { Bivoltine } \\
\uparrow \\
\text { Univoltine } \\
\text { (Recessivation) }\end{array}$ \\
\hline $\begin{array}{l}\text { Increase } \\
\text { of SG } \\
\text { hormone } \\
\text { (high in- } \\
\text { cubating } \\
\text { temper- } \\
\text { ature }\end{array}$ & More & Less & Less & More & Fall & $\begin{array}{l}\text { Trimolting } \\
\downarrow \\
\text { Tetramolting } \\
\downarrow \\
\text { Pentamolting } \\
\text { (Recessivation) }\end{array}$ & $\begin{array}{l}\text { Multivoltine } \\
\downarrow \\
\text { Bivoltine } \\
\downarrow \\
\text { Univoltine } \\
\text { (Domination) }\end{array}$ \\
\hline
\end{tabular}

tics are shown in Table VI.

Acknowledgement. We are grateful for a grant for scientific research from the Ministry of Education.

\section{References}

Bito, S. (1936): Rep. Ibaraki Sericult. Sta., 7, 1-16.

Bubois, M., Gilles, K. A., Hamilton, J. K., Rebers, P. A., and Smith, F. (1956):

Anal Chem., 28, 350-356.

Coles, G. C. (1964): Nature Lond., 203, 323.

- (1965): J. Exp. Biol., 43, 425-431.

Hill, L. (1965): J. Ins. Physiol., 11, 1605-1615.

Lüscher, Martin (1968): J. Ins. Physiol., 14, 499-511.

Hasegawa, K., and Yamashita, O. (1967): J. Sericult. Sci. Japan, 36, 297-301.

Morohoshi, S. (1957): Japan Soc. Prom. Sci., 1-202 (book).

Morohoshi S., and Ohkuma, T. (1968): J. Sericult. Japan, 37, 375-384.

Morohoshi, S., and Oshiki, T. (1969): Proc. Japan Acad., 45, 308-313 (1069).

Morohoshi, S., and Kiguchi, K. (1969): Proc. Japan Acad., 45, 323-327 (1969).

Odhiambo, T. R. (1965): Nature Lond., 207, 1314-1316.

- (1966): J. Exp. Biol., 45, 45-50.

Ralph, C. L. (1962): J. Ins. Physiol., 8, 431-439.

Vanderberg, J. P. (1963 a): Biol. Bull. Woods Hole, 125, 556-575.

- (1963 b): Biol. Bull. Woods Hole, 125, 576-581.

Yamashita, O., and Hasegawa, K. (1963): J. Tokai Branchi Sericult. Sci. Japan,

11, 23.

(1964): J. Tokai Branchi Sericult. Sci. Japan, 12, $21-22$.

(1965): J. Sericult. Sci. Japan, 34, 235-243. 